\title{
Marinobacter goseongensis sp. nov., from seawater
}

Correspondence

Jin-Woo Bae

baejw@kribb.re.kr

\author{
Seong Woon Roh, ${ }^{1,2}$ Zhe-Xue Quan, ${ }^{3}$ Young-Do Nam, ${ }^{1,2}$ Ho-Won Chang, ${ }^{2}$ \\ Kyoung-Ho Kim, ${ }^{2}$ Sung-Keun Rhee, ${ }^{4}$ Hee-Mock Oh, ${ }^{2}$ Che Ok Jeon, ${ }^{5}$ \\ Jung-Hoon Yoon ${ }^{2}$ and Jin-Woo Bae $e^{1,2,5}$ \\ ${ }^{1}$ Korea University of Science and Technology, Daejeon 305-333, Republic of Korea \\ ${ }^{2}$ Biological Resource Center, KRIBB, Daejeon 305-806, Republic of Korea \\ ${ }^{3}$ School of Life Sciences, Fudan University, Shanghai 200433, PR China \\ ${ }^{4}$ Department of Microbiology, Chungbuk National University, Cheongju 361-763, Republic of Korea \\ ${ }^{5}$ Environmental Biotechnology National Core Research Center, Gyeongsang National University, \\ Jinju 660-701, Republic of Korea
}

\begin{abstract}
A Gram-negative marine bacterium, designated strain $\mathrm{En}^{\top}{ }^{\top}$, was isolated from seawater of the East Sea of Korea. The organism grew in $1-25 \%(\mathrm{w} / \mathrm{v}) \mathrm{NaCl}$ and at $10-37{ }^{\circ} \mathrm{C}$ and $\mathrm{pH} 5.3-9.3$, with optimal growth occurring in $4-5 \% \mathrm{NaCl}$ and at $25-30{ }^{\circ} \mathrm{C}$ and $\mathrm{pH}$ 7.5. Phylogenetic analysis of the 16S rRNA gene sequence of strain $\mathrm{En}^{\top}{ }^{\top}$ placed this bacterium in the clade Marinobacter within the class Gammaproteobacteria. The 16S rRNA gene sequence similarity between strain $\mathrm{En}^{\top}{ }^{\top}$ and Marinobacter lipolyticus SM19 ${ }^{\top}$, the most closely related species, was $98.4 \%$, and the level of DNA-DNA relatedness between the two strains was $22 \%$. On the basis of the phylogenetic analysis and phenotypic and chemotaxonomic data, strain $\mathrm{En}^{\top}{ }^{\top}$ is considered to represent a novel species of the genus Marinobacter. The name Marinobacter goseongensis sp. nov. is proposed, with strain $\mathrm{En}^{\top}\left(=\mathrm{KCTC} 12515^{\top}=\mathrm{DSM} 19471^{\top}\right)$ as the type strain.
\end{abstract}

The genus Marinobacter, within the class Gammaproteobacteria, was first proposed by Gauthier et al., (1992) to accommodate a Gram-negative, aerobic, rod-shaped bacterium that was isolated from Mediterranean seawater. Since this genus was proposed in 1992, more than 15 species of Marinobacter have been isolated from various environments, including: seawater (Antunes et al., 2007; Gauthier et al., 1992; Shivaji et al., 2005; Yoon et al., 2003, 2004), oilproducing well (Huu et al., 1999), marine sediment (Gorshkova et al., 2003; Romanenko et al., 2005), saline soil (Gu et al., 2007; Martin et al., 2003), coastal hot spring (Shieh et al., 2003), wastewater (Liebgott et al., 2006), laboratory cultures of dinoflagellates (Green et al., 2006) and sea sand (Kim et al., 2006). In this paper, the taxonomic position of strain $\mathrm{En}^{\mathrm{T}}$ was established by means of phenotypic, genetic and chemotaxonomic analyses.

A single novel strain, designated $\mathrm{En} 6^{\mathrm{T}}$, was isolated from coastal seawater of the East Sea of Korea at a depth of $100 \mathrm{~m}$, by using a dilution-plating technique on marine agar 2216 (MA; Difco). The colonies were repeatedly restreaked to obtain a pure culture and the 16S rRNA gene of the strain was sequenced. Growth at various temperatures $\left(4-45^{\circ} \mathrm{C}\right)$ and $\mathrm{pH}$ values $(\mathrm{pH} 3.0-12.0)$ was examined using marine broth (MB; Difco). The requirement

The GenBank/EMBL/DDBJ accession number for the 16S rRNA gene sequence of strain $E n 6^{\top}$ is EF660754. and tolerance of various $\mathrm{NaCl}$ concentrations (0-30\%) were determined in broth medium that comprised all of the constituents of $\mathrm{MB}$, except $\mathrm{NaCl}$, supplemented with appropriate concentrations of $\mathrm{NaCl}$. Growth at various temperatures and $\mathrm{pH}$ values and in various concentrations of $\mathrm{NaCl}$ was determined in triplicate and sequencing of the $16 \mathrm{~S}$ rRNA gene was performed in triplicate to check the purity of the novel strain. Cell morphology was examined by using light microscopy (ECLIPSE $80 i$; Nikon) and electron microscopy. The Gram-reaction was determined by using a Gram Stain kit (Difco), according to the manufacturer's instructions. Motility was examined by using the wet-mount method and spore formation was determined using the staining method (Schaeffer \& Fulton, 1933). Hydrolysis of gelatin and starch was determined as described by Smibert \& Krieg (1994). The heat resistance of cells was determined as described by Guo et al. (2007). API ZYM test strips with suspension medium $(0.85 \% \mathrm{NaCl}$ in demineralized water) (bioMérieux) were used to analyse traits of strain $\mathrm{En}^{\mathrm{T}}$ in triplicate, according to the manufacturer's instructions. Utilization of organic substrates was determined using Biolog GN2 plates consisting of 95 substrates and GN (Gram-negative)/GP (Grampositive) inoculating fluid $(0.40 \% \mathrm{NaCl}, 0.03 \%$ Pluronic F-68 and $0.02 \%$ Gellan gum) with the salinity adjusted to $5 \%(\mathrm{w} / \mathrm{v}) \mathrm{NaCl}$, according to the manufacturer's instructions. Catalase activity was determined by using bubble 
production in $3 \%(\mathrm{v} / \mathrm{v})$ hydrogen peroxide solution, and oxidase activity was determined using an oxidase reagent (bioMérieux), in triplicate using MA. Cells of strain En6 ${ }^{\mathrm{T}}$ were Gram-negative and oxidase- and catalase-positive. Gelatin and starch were not hydrolysed. No spores were produced and the cells were not resistant to heat. Optimal growth occurred at $25-30{ }^{\circ} \mathrm{C}$ and $\mathrm{pH} 7.5$, and in $4-5 \%$ (w/v) $\mathrm{NaCl}$. Comparisons of additional characteristics and results of biochemical and physiological assays for strain $\mathrm{En}^{\mathrm{T}}$ and the type strains of its closest relatives in the phylogenetic tree, are shown in Table 1. Strain $\mathrm{En}^{\mathrm{T}}$ was able to grow in $25 \% \mathrm{NaCl}$, but five closely related species were not. On the other hand, strain $\mathrm{En}^{\mathrm{T}}$ did not grow at $40{ }^{\circ} \mathrm{C}$, whereas the other Marinobacter species used could. Together, these data clearly differentiate the novel isolate from other closely related species.

Fatty acid methyl esters of cells of strain $\mathrm{En} 6^{\mathrm{T}}$ and reference strains grown on $\mathrm{MA}$ at $30{ }^{\circ} \mathrm{C}$ for 2 days were analysed, according to standard protocols provided by the MIDI/ Hewlett Packard Microbial Identification System (Sasser, 1990). The fatty acid composition of strain En $6^{\mathrm{T}}$ is shown in Table 2. Strain En $6^{\mathrm{T}}$ had a relatively high content of the fatty acid $\mathrm{C}_{18: 1} \omega 9 c(31.5 \%)$, compared with the contents (21.6-24.7\%) of the type strains of its closest relatives, as shown in Table 2.

Chromosomal DNA was extracted and purified using a DNA extraction kit (iNtRON Biotechnology), and was used as a template with two bacterial universal primers for PCR amplification of the 16S rRNA gene, as described previously (Baker et al., 2003). The PCR product was purified using a QIAquick PCR Purification kit (Qiagen) and sequenced as described previously (Roh et al., 2008). DNA-DNA hybridization was performed using the fluorometric method of Ezaki et al. (1989). The 16S rRNA gene sequence of the novel isolate was aligned with 20 reference sequences from the NCBI database by using the multiple sequence alignment program CLUSTAL_X (1.8) (Thompson et al., 1997). Calculation of pairwise 16S rRNA gene sequence similarities were achieved using the EzTaxon server (http://www.eztaxon.org/; Chun et al.. 2007). Phylogenetic relationships between representatives of the genus Marinobacter were determined using the program

Table 1. Phenotypic characteristics that differentiate strain $\mathrm{En} 6^{\top}$ (Marinobacter goseongensis sp. nov.) from phylogenetically related species

Strains: 1, En6 ${ }^{\mathrm{T}}$ (data from the present study); 2, M. lipolyticus SM19 ${ }^{\mathrm{T}}$ (Martin et al., 2003); 3, M. sediminum $\mathrm{R}^{\mathrm{T}}{ }^{\mathrm{T}}$ (Romanenko et al., 2005); 4 , M. flavimaris SW-145 ${ }^{\mathrm{T}}$ (Yoon et al., 2004); 5, M. algicola DG893 ${ }^{\mathrm{T}}$ (Green et al., 2006); 6, M. salsuginis SD-14B ${ }^{\mathrm{T}}$ (Antunes et al., 2007). +, Positive; -, negative; $\mathrm{W}$, weak reaction; ND, not determined.

\begin{tabular}{|c|c|c|c|c|c|c|}
\hline Characteristic & 1 & 2 & 3 & 4 & 5 & 6 \\
\hline \multicolumn{7}{|l|}{ Growth at/in: } \\
\hline $4{ }^{\circ} \mathrm{C}$ & - & - & + & + & ND & - \\
\hline Maximum $\mathrm{NaCl}$ for growth (\%) & 25 & 15 & 18 & 20 & 12 & 20 \\
\hline $\begin{array}{l}\text { Maximum temperature for } \\
\text { growth }\left({ }^{\circ} \mathrm{C}\right)\end{array}$ & 37 & 40 & 42 & 45 & 40 & 45 \\
\hline Gelatin & - & - & - & - & - & + \\
\hline Starch & - & - & ND & - & + & - \\
\hline \multicolumn{7}{|l|}{ Utilization of: } \\
\hline D-Fructose & - & + & - & + & + & - \\
\hline D-Glucose & - & + & + & - & + & + \\
\hline L-Glutamic acid & + & - & - & - & - & ND \\
\hline Proline & - & - & - & $t^{*}$ & + & + \\
\hline \multicolumn{7}{|l|}{ API ZYM tests } \\
\hline Esterase (C4) & + & ND & - & + & ND & + \\
\hline Lipase $(\mathrm{C} 14)$ & - & ND & - & + & ND & + \\
\hline Valine arylamidase & + & ND & - & - & ND & $\mathrm{w}$ \\
\hline Cystine arylamidase & + & ND & - & - & ND & $\mathrm{w}$ \\
\hline Acid phosphatase & + & ND & - & + & ND & w \\
\hline$N$-acetyl- $\beta$-glucosaminidase & + & $\mathrm{ND}$ & - & + & $\mathrm{ND}$ & + \\
\hline
\end{tabular}

${ }^{\star}$ Data from Green et al. (2006). 
Table 2. Fatty acid contents of strain $\mathrm{En}^{\top}{ }^{\top}$ (Marinobacter goseongensis sp. nov.) and closely related Marinobacter species

Strains: 1, En6 ${ }^{\mathrm{T}} ; 2$, M. lipolyticus $\mathrm{SM} 19^{\mathrm{T}} ; 3$, M. sediminum $\mathrm{R} 65^{\mathrm{T}} ; 4$, M. flavimaris $\mathrm{SW}-145^{\mathrm{T}}$. All data are from this study. Values are percentages of the total fatty acids.

\begin{tabular}{|lrrrr|}
\hline Fatty acid & \multicolumn{1}{c}{} & \multicolumn{1}{c}{$\mathbf{2}$} & \multicolumn{1}{c|}{$\mathbf{3}$} & \multicolumn{1}{c|}{$\mathbf{4}$} \\
\hline $\mathrm{C}_{10: 0}$ & 0.5 & 1.3 & 1.8 & 0.3 \\
$\mathrm{C}_{12: 0}$ (6.5 & 6.1 & 4.0 & 6.2 \\
$\mathrm{C}_{12: 0} 3-\mathrm{OH}$ & 9.2 & 9.0 & 7.4 & 8.0 \\
$\mathrm{C}_{14: 0}$ & 1.1 & 0.5 & 1.0 & 0.9 \\
$\mathrm{C}_{15: 0}$ & 0.5 & 0.4 & 0.1 & 0.4 \\
$\mathrm{C}_{16: 0}$ & 27.2 & 24.5 & 21.2 & 25.4 \\
$\mathrm{C}_{16: 1} \omega 9 c$ & 13.6 & 8.6 & 6.8 & 8.0 \\
$\mathrm{C}_{16: 1} \omega 7 c / 15$ iso 2-OH & 2.5 & 6.8 & 8.8 & 9.7 \\
$\mathrm{C}_{16: 0} 10-\mathrm{methyl}$ & 0.9 & 3.2 & 1.7 & 0.3 \\
$\mathrm{C}_{17: 1} \omega 8 c$ & 1.0 & 2.5 & 2.0 & 2.7 \\
$\mathrm{C}_{17: 0}$ & 1.3 & 2.2 & 1.7 & 2.2 \\
$\mathrm{C}_{18: 1} \omega 9 c$ & 31.5 & 23.6 & 21.6 & 24.7 \\
$\mathrm{C}_{18: 1} \omega 7 c$ & 0.7 & 4.1 & 5.6 & 1.6 \\
$\mathrm{C}_{18: 0}$ & 1.9 & 3.3 & 5.8 & 3.9 \\
\hline
\end{tabular}

MEGA3 (Kumar et al., 2004). Distance matrices were determined according to the assumptions described by Kimura (1980) and were used to develop dendrograms with the neighbour-joining method (Saitou \& Nei, 1987). Bootstrap analysis of the stability of the predicted trees was performed by compiling a consensus tree based on 1000 randomly generated trees. Fig. 1 shows that strain $E n 6^{\mathrm{T}}$ fell within the cluster of Marinobacter species. According to the 16S rRNA gene sequences, strain En $6^{\mathrm{T}}$ showed a high level of similarity with Marinobacter lipolyticus SM19 ${ }^{\mathrm{T}}$ (98.4\%), Marinobacter gudaonensis SL014B61A ${ }^{\mathrm{T}} \quad(97.8 \%)$, Marinobacter sediminum $\mathrm{R}^{\mathrm{T}} 5^{\mathrm{T}}(97.5 \%)$, Marinobacter algicola $\mathrm{DG} 83^{\mathrm{T}}$ (97.1\%), Marinobacter salsuginis SD$14 \mathrm{~B}^{\mathrm{T}}(97.1 \%)$ and Marinobacter flavimaris $\mathrm{SW}-145^{\mathrm{T}}$ (97.0\%). DNA-DNA relatedness studies were performed to determine the genomic relationship between strain En $^{\mathrm{T}}$ and the type strains of its closest relatives in the phylogenetic tree. Levels of DNA-DNA relatedness of 22, 17 and $26 \%$ between strain En6 ${ }^{\mathrm{T}}$ and M. lipolyticus $\mathrm{SM} 19^{\mathrm{T}}$, M. sediminum $\mathrm{R} 65^{\mathrm{T}}$ and $M$. flavimaris $\mathrm{SW}-145^{\mathrm{T}}$ were obtained, respectively.

Therefore, based on the comparison of the phenotypic, genetic and chemotaxonomic data for previously described

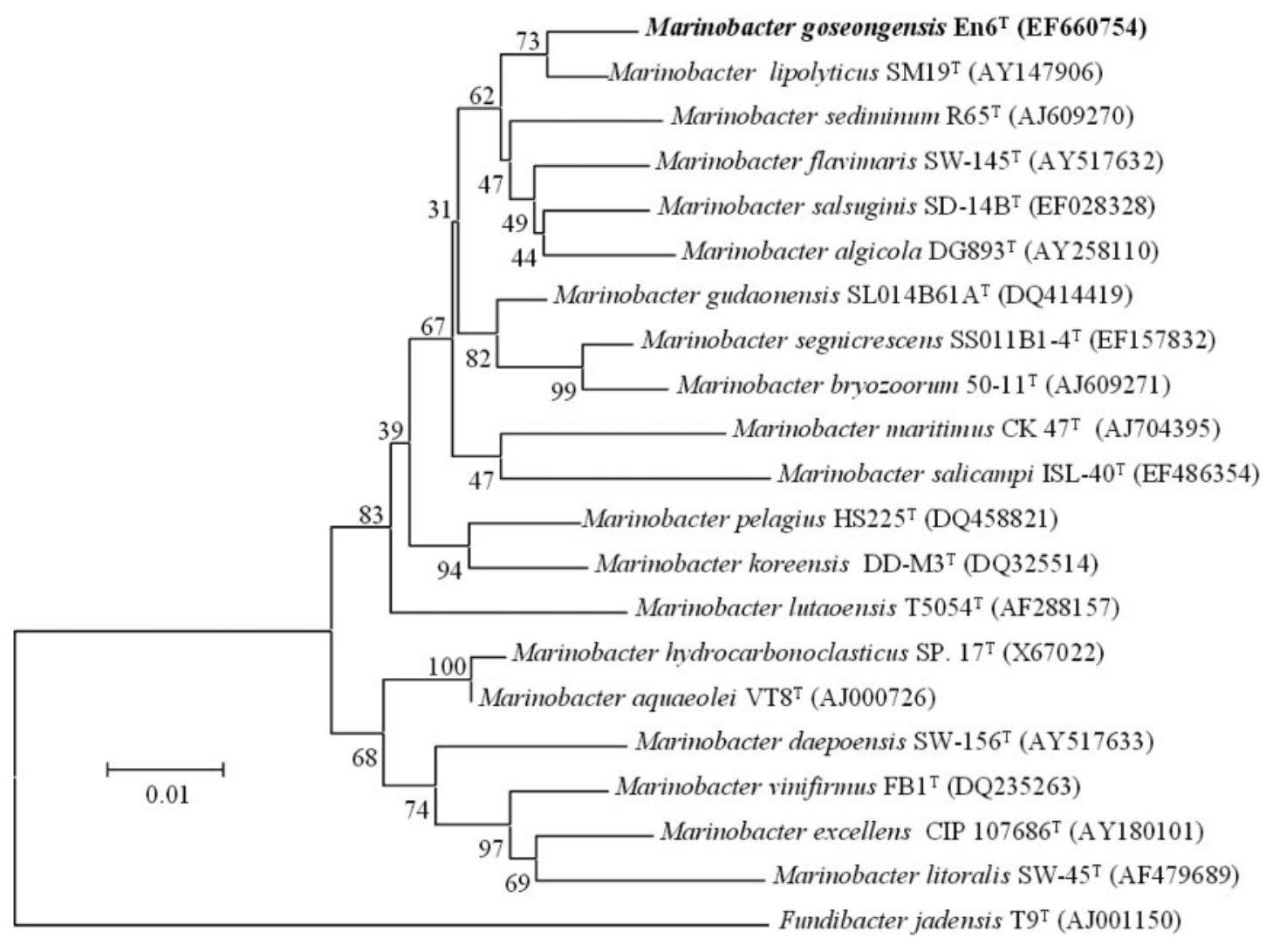

Fig. 1. Phylogenetic dendrogram based on unambiguously aligned base pairs of $16 \mathrm{~S}$ rRNA gene sequence data, showing the position of strain $\mathrm{En}^{\top}{ }^{\top}$ (Marinobacter goseongensis sp. nov.). The tree was generated using the neighbour-joining method. Numbers at nodes are bootstrap percentages (based on 1000 replications). GenBank/EMBL/DDBJ accession numbers are given in parentheses. Bar, 0.01 accumulated changes per nucleotide. 
taxa, strain $\mathrm{En} 6^{\mathrm{T}}$ is considered to represent a novel species of the genus Marinobacter, for which the name Marinobacter goseongensis sp. nov. is proposed.

\section{Description of Marinobacter goseongensis sp. nov.}

Marinobacter goseongensis (go'se.on.gen'sis. N.L. masc. adj. goseongensis pertaining to the province Goseong, near the sampling site from which the bacterium was isolated).

Cells are rod-shaped $(0.5-0.8 \times 1.6-2.0 \mu \mathrm{m})$, Gram-negative, non-motile, oxidase- and catalase-positive and nonspore-forming. Cells are not heat resistant. Colonies are cream-coloured, circular and approximately $0.5 \mathrm{~mm}$ in diameter after growth for 1 day on $\mathrm{MA}$ at $30{ }^{\circ} \mathrm{C}$. Growth occurs at $10-37^{\circ} \mathrm{C}$ (optimum, $25-30{ }^{\circ} \mathrm{C}$ ) and $\mathrm{pH} 5.3-9.3$ (optimum, $\mathrm{pH} 7.5$ ) and in $1-25 \%(\mathrm{w} / \mathrm{v}) \mathrm{NaCl}$ (optimum, $4-5 \% \mathrm{NaCl}$ ). Gelatin and starch are not hydrolysed. According to Biolog GN plates, positive for Tween 40, Tween 80, pyruvic acid methyl ester, acetic acid, DL-lactic acid and L-glutamic acid; and negative for $\alpha$-cyclodextrin, dextrin, glycogen, $\mathrm{N}$-acetyl-D-galactosamine, $\mathrm{N}$-acetyl-Dglucosamine, adonitol, L-arabinose, D-arabitol, D-cellobiose, i-erythritol, D-fructose, L-fucose, D-galactose, gentiobiose, $\alpha$-D-glucose, myo-inositol, $\alpha$-D-lactose, lactulose, maltose, D-mannitol, D-mannose, melibiose, methyl $\beta$-Dglucoside, D-psicose, raffinose, L-rhamnose, D-sorbitol, sucrose, trehalose, turanose, xylitol, succinic acid monomethyl ester, cis-aconitic acid, citric acid, formic acid, Dgalactonic acid lactone, D-galacturonic acid, D-gluconic acid, D-glucosaminic acid, D-glucuronic acid, $\alpha$-hydroxybutyric acid, $\beta$-hydroxybutyric acid, $\gamma$-hydroxybutyric acid, $p$-hydroxyphenylacetic acid, itaconic acid, $\alpha$-ketobutyric acid, $\alpha$-ketoglutaric acid, $\alpha$-ketovaleric acid, malonic acid, propionic acid, quinic acid, D-saccharic acid, sebacic acid, succinic acid, bromosuccinic acid, succinamic acid, glucuronamide, L-alaninamide, D-alanine, L-alanine, Lalanyl glycine, L-asparagine, L-aspartic acid, glycyl Laspartic acid, glycyl L-glutamic acid, L-histidine, hydroxyL-proline, L-leucine, L-ornithine, L-phenylalanine, L-proline, L-pyroglutamic acid, D-serine, L-serine, L-threonine, DL-carnitine, $\gamma$-aminobutyric acid, urocanic acid, inosine, uridine, thymidine, phenyethylamine, putrescine, 2-aminoethanol, 2,3-butanediol, glycerol, DL- $\alpha$-glycerol phosphate, $\alpha$-D-glucose 1-phosphate and D-glucose 6phosphate. According to API ZYM test strips, positive for alkaline phosphatase, esterase (C4), esterase lipase (C8), leucine arylamidase, valine arylamidase, cystine arylamidase, acid phosphatase, naphthol-AS-B1-phosphohydrolase and $N$-acetyl- $\beta$-glucosaminidase activities; and negative for lipase (C14), trypsin, $\alpha$-chymotrypsin, $\alpha$-galactosidase, $\beta$ galactosidase, $\beta$-glucuronidase, $\alpha$-glucosidase, $\beta$-glucosidase, $\alpha$-mannosidase and $\alpha$-fucosidase activities. Predominant fatty acids are $\mathrm{C}_{12: 0}, \mathrm{C}_{12: 0} 3-\mathrm{OH}, \mathrm{C}_{16: 0}$, $\mathrm{C}_{16: 1} \omega 9 c$ and $\mathrm{C}_{18: 1} \omega 9 c$ (Table 2).

The type strain, En6 $6^{\mathrm{T}}\left(=\right.$ KCTC $\left.12515^{\mathrm{T}}=\mathrm{DSM} 19471^{\mathrm{T}}\right)$, was isolated from seawater of the East Sea of Korea.

\section{Acknowledgements}

This work was supported by the KRIBB Research Initiative Program, the Environmental Biotechnology National Core Research Center (KOSEF: R15-2003-012-02002-0) and Conservation Technology Research and Development project hosted by National Research Institute of Cultural Heritage of Cultural Heritage Administration.

\section{References}

Antunes, A., Franca, L., Rainey, F. A., Huber, R., Nobre, M. F., Edwards, K. J. \& da Costa, M. S. (2007). Marinobacter salsuginis sp. nov., isolated from the brine-seawater interface of the Shaban Deep, Red Sea. Int J Syst Evol Microbiol 57, 1035-1040.

Baker, G. C., Smith, J. J. \& Cowan, D. A. (2003). Review and reanalysis of domain-specific $16 \mathrm{~S}$ primers. J Microbiol Methods 55, 541555.

Chun, J., Lee, J.-H., Jung, Y., Kim, M., Kim, S., Kim, B. K. \& Lim, Y.-W. (2007). EzTaxon: a web-based tool for the identification of prokaryotes based on $16 \mathrm{~S}$ ribosomal RNA gene sequences. Int J Syst Evol Microbiol 57, 2259-2261.

Ezaki, T., Hashimoto, Y. \& Yabuuchi, E. (1989). Fluorometric deoxyribonucleic acid-deoxyribonucleic acid hybridization in microdilution wells as an alternative to membrane filter hybridization in which radioisotopes are used to determine genetic relatedness among bacterial strains. Int J Syst Bacteriol 39, 224-229.

Gauthier, M. J., Lafay, B., Christen, R., Fernandez, L., Acquaviva, M., Bonin, P. \& Bertrand, J. C. (1992). Marinobacter hydrocarbonoclasticus gen. nov., sp. nov., a new, extremely halotolerant, hydrocarbondegrading marine bacterium. Int J Syst Bacteriol 42, 568-576.

Gorshkova, N. M., Ivanova, E. P., Sergeev, A. F., Zhukova, N. V., Alexeeva, Y., Wright, J. P., Nicolau, D. V., Mikhailov, V. V. \& Christen, R. (2003). Marinobacter excellens sp. nov., isolated from sediments of the Sea of Japan. Int J Syst Evol Microbiol 53, 2073-2078.

Green, D. H., Bowman, J. P., Smith, E. A., Gutierrez, T. \& Bolch, C. J. (2006). Marinobacter algicola sp. nov., isolated from laboratory cultures of paralytic shellfish toxin-producing dinoflagellates. Int $J$ Syst Evol Microbiol 56, 523-527.

Gu, J., Cai, H., Yu, S.-L., Qu, R., Yin, B., Guo, Y.-F., Zhao, J.-Y. \& Wu, X.-L. (2007). Marinobacter gudaonensis sp. nov., isolated from an oilpolluted saline soil in a Chinese oilfield. Int J Syst Evol Microbiol 57, 250-254.

Guo, B., Gu, J., Ye, Y.-G., Tang, Y.-Q., Kida, K. \& Wu, X.-L. (2007). Marinobacter segnicrescens sp. nov., a moderate halophile isolated from benthic sediment of the South China Sea. Int J Syst Evol Microbiol 57, 1970-1974.

Huu, N. B., Denner, E. B., Ha, D. T., Wanner, G. \& Stan-Lotter, H. (1999). Marinobacter aquaeolei sp. nov., a halophilic bacterium isolated from a Vietnamese oil-producing well. Int J Syst Bacteriol 49, 367-375.

Kim, B.-Y., Weon, H.-Y., Yoo, S.-H., Kim, J.-S., Kwon, S.-W., Stackebrandt, E. \& Go, S.-J. (2006). Marinobacter koreensis sp. nov., isolated from sea sand in Korea. Int J Syst Evol Microbiol 56, 2653-2656.

Kimura, M. (1980). A simple method for estimating evolutionary rates of base substitutions through comparative studies of nucleotide sequences. J Mol Evol 16, 111-120.

Kumar, S., Tamura, K. \& Nei, M. (2004). MEGA3: integrated software for Molecular Evolutionary Genetics Analysis and sequence alignment. Brief Bioinform 5, 150-163.

Liebgott, P.-P., Casalot, L., Paillard, S., Lorquin, J. \& Labat, M. (2006). Marinobacter vinifirmus sp. nov., a moderately halophilic bacterium 
isolated from a wine-barrel-decalcification wastewater. Int J Syst Evol Microbiol 56, 2511-2516.

Martin, S., Márquez, M. C., Sánchez-Porro, C., Mellado, E., Arahal, D. R. \& Ventosa, A. (2003). Marinobacter lipolyticus sp. nov., a novel moderate halophile with lipolytic activity. Int J Syst Evol Microbiol 53, 1383-1387.

Roh, S. W., Sung, Y., Nam, Y. D., Chang, H. W., Kim, K. H., Yoon, J. H., Jeon, C. O., Oh, H. M. \& Bae, J. W. (2008). Arthrobacter soli sp. nov., a novel bacterium isolated from wastewater reservoir sediment. J Microbiol 46, 40-44.

Romanenko, L. A., Schumann, P., Rohde, M., Zhukova, N. V., Mikhailov, V. V. \& Stackebrandt, E. (2005). Marinobacter bryozoorum sp. nov. and Marinobacter sediminum sp. nov., novel bacteria from the marine environment. Int J Syst Evol Microbiol 55, 143-148.

Saitou, N. \& Nei, M. (1987). The neighbor-joining method: a new method for reconstructing phylogenetic trees. Mol Biol Evol 4, 406-425.

Sasser, M. (1990). Identification of bacteria by gas chromatography of cellular fatty acids, MIDI Technical Note 101. Newark, DE: MIDI Inc.

Schaeffer, A. B. \& Fulton, M. D. (1933). A simplified method of staining endospores. Science 77, 194.

Shieh, W. Y., Jean, W. D., Lin, Y. T. \& Tseng, M. (2003). Marinobacter lutaoensis sp. nov., a thermotolerant marine bacterium isolated from a coastal hot spring in Lutao, Taiwan. Can J Microbiol 49, 244252.

Shivaji, S., Gupta, P., Chaturvedi, P., Suresh, K. \& Delille, D. (2005). Marinobacter maritimus sp. nov., a psychrotolerant strain isolated from sea water off the subantarctic Kerguelen islands. Int J Syst Evol Microbiol 55, 1453-1456.

Smibert, R. M. \& Krieg, N. R. (1994). Phenotypic characterization. In Methods for General and Molecular Bacteriology, pp. 607-654. Edited by P. Gerhardt, R. G. E. Murray, W. A. Wood \& N. R. Krieg. Washington, DC: American Society for Microbiology.

Thompson, J. D., Gibson, T. J., Plewniak, F., Jeanmougin, F. \& Higgins, D. G. (1997). The CLUSTAL_X windows interface: flexible strategies for multiple sequence alignment aided by quality analysis tools. Nucleic Acids Res 25, 4876-4882.

Yoon, J.-H., Shin, D.-Y., Kim, I.-G., Kang, K. H. \& Park, Y.-H. (2003). Marinobacter litoralis sp. nov., a moderately halophilic bacterium isolated from sea water from the East Sea in Korea. Int J Syst Evol Microbiol 53, 563-568.

Yoon, J.-H., Yeo, S.-H., Kim, I.-G. \& Oh, T.-K. (2004). Marinobacter flavimaris sp. nov. and Marinobacter daepoensis sp. nov., slightly halophilic organisms isolated from sea water of the Yellow Sea in Korea. Int J Syst Evol Microbiol 54, 1799-1803. 